ECONOMICS

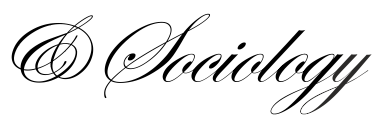

Korsakienè, R., Raišienè, A. G., Bužavaitè, M. (2017). Work Engagement of Older Employees: do Employee and Work-Related Factors Matter? Economics and Sociology, 10(4), 151-161. doi:10.14254/2071-789X.2017/10-4/12

\author{
Renata Korsakienė, \\ The General Jonas Žemaitis \\ Military Academy of Lithuania, \\ Vilnius, Lithuania, \\ Vilnius Gediminas Technical \\ University, \\ Vilnius, Lithuania, \\ E-mail: renata.korsakiene@vgtu.lt
}

Agota Giedrè Raišienè, Mykolas Romeris University, Vilnius, Lithuania,

E-mail:agotar@mruni.eu

\author{
Monika Bužavaitè, \\ Valuetech s.r.l., \\ Corso Re Umberto, \\ Torino, Italy, \\ E-mail: \\ monikaburavaite@gmail.com
}

Received: March, 2017

1st Revision: August, 2017

Accepted: September, 2017

DOI: $10.14254 / 2071-$

789X.2017/10-4/12

JEL Classification: M10, M12

\section{WORK ENGAGEMENT OF OLDER EMPLOYEES: DO EMPLOYEE AND WORK-RELATED FACTORS MATTER?}

\begin{abstract}
Today's shortage of qualified workers due to population aging and emigration requires putting more emphasis on older employees and also developing specific measures so that to increase their work engagement. However, employers prefer to hire younger individuals who are assumed to be flexible, and more acquainted with new information technologies. Meanwhile, older employees are seen as less engaged in work, less familiar with lifelong learning and also coping with deteriorating health issues. This paper focuses on older employees working in science, education and public organizations of Lithuania. Being grounded on the prevailing theories in this regard, the paper aims to investigate employee- and work-related factors around this problem. The data obtained allows us confirm that work scheduling autonomy, decision-making autonomy, managerial orientation, career achievement, dedication to work, feedback from work influence work engagement of older employees. The study let us develop insights for managers and recommendations for future investigations in the same field.
\end{abstract}

Keywords: work engagement, employee-related factors, workrelated factors, older employees, age related factors

\title{
Introduction
}

The aging of population is seen as one of the most concerning social phenomenon of this century. Many countries have to deal with this problem, except some of African and Asian countries. The explanation resides in the fact that in Europe the fertility rate is 1.5, while in Africa it is on average 4.6 children per woman. Meanwhile, the fertility level in other continents achieves the following average ratio: in Oceania - 2.5, Latin America - 2.3, North America and Asia - about 2. Meanwhile, some forecasts suggest that one of five individuals 
will be older than 60 years in the middle of the $\mathrm{XXI}^{\text {st }}$ century (Department of Economic and..., 2015).

It is frequently observed that young families decide to have children only after completed studies and integration into the labor market. These decisions of young individuals and the demographic situation impacted the critical level of fertility rate and also have its negative influence on some other socially important areas, like the pension system etc. The labor force is also aging. The EU statistical data reveals that older individuals comprised 42,2\% of all employees in 2005; 46,7\% - in 2010 and 53,3\% - in 2015 (Eurostat, 2016). Therefore, legislators, institutions, politicians, employers, managers, employees of all ages and the whole society are facing new challenges (Vasconcelos, 2015).

The European Commission sets ambitious targets to boost economic activity of older individuals through the pension systems. Thus, unfavorable demographic situation has led to the extension of the retirement age in the EU and older employees have to remain active at the labor market longer than before. While social partners suggest various initiatives that allow older employees remain active at the labor market (Flynn, 2010), employers also aim to encourage older employees to delay the retirement.

The aging of population and the growth of older employees' percentage in organizations are interrelated with the integration of older employees at the labor market (Bejtkovský, 2016). Thus, from the human resource management perspective, it is important to understand the factors facilitating work engagement of older employees. These considerations have to be taken into account while human resource management strategy is developed. The current situation reveals that employers prefer to hire younger individuals with appropriate education. In comparison to younger employees, older employees are less engaged in work. This issue can be explained by the rapid development of information technologies, constant learning and adaptation process, which are less accepted by older employees. In addition, older generation is less familiar with lifelong learning, while it has to cope with deteriorating health problems etc.

The literature on older employees and the factors impacting their work engagement is expanding, however, a number of investigations have been carried out in the developed countries context. Meanwhile, investigations, carried out in the emerging markets' context are limited in number (Goštautaitè, 2014; Goštautaite \& Bučiūnienè, 2015). Thus, investigation of factors impacting work engagement of the older employees is a fruitful venue in scientific literature. Grounded on the prevailing theories, this paper aims to investigate employee- and work-related factors. The paper is structured as follows. First, work-, employee- and agerelated factors and characteristics are revised. The next section defines the research sample, research methodology and data composition. The next section presents the research findings and discussion. Finally, conclusions and recommendations for future investigations are suggested.

\section{Factors determining work engagement of older employees}

Scientific studies, focused on work engagement of older employees', define this phenomenon as employees' self-determined work and intentions to remain with current employer. Thus, the researchers considered work engagement as a relatively stable motivational and individual difference variable (Park \& Gursoy, 2012). Older employees continue working if they are successfully convinced to remain with the organization (Armstrong-Stassen \& Ursel, 2009). Meanwhile, early retirement is seen as the outcome of poor work engagement. Notably, work engagement of older employees' is determined by the factors related to employee, work and organization. The factors, related to the organization, distinguish low level of independence while doing everyday tasks, high psychological tension 
and weak relationships with organization. From the perspective of employee, the early retirement is determined by health and financial status. While the decision to retire is related to the life and work balance, personal characteristics such as age or gender are less clearly defined. Flynn (2010) determined the following factors, impacting work engagement of employees: national employment laws, pension provision laws, family circumstances and employers' attitude and behavior towards older employees. The ongoing debates about the work engagement factors provide competing approaches and insights. Thus, we will focus on some of the most important factors, impacting work engagement of older employees. Considering prevailing scientific studies, these factors are grouped into four main categories: work related factors, employee related factors, age related factors and demographic characteristics.

\subsection{Work related factors}

Scientific literature, focused on work related factors, is vast. Though various researches report different factors, the majority of studies rely on motivational (intrinsic) work characteristics, social (relational) work characteristics, and work characteristics related to the work context (e.g. Humphrey et al., 2007; Morgeson \& Humphrey, 2006). For instance, some of motivational factors include task identity and task significance. While task identity refers to the degree, to which an employee completes a whole piece of work, task significance is defined as the impact that a job has on the lives or work of other individuals (Goštautaite, 2014). Thus, individuals whose job influences others physical or psychological well-being experience greater meaningfulness in the work (Morgeson \& Humphrey, 2006).

Meanwhile, autonomy is the most analyzed work related factor, included in majority of work engagement models. Notably, autonomy is interrelated to work scheduling, decision making and selection of the methods used to perform tasks (Morgeson \& Humphrey, 2006). The research carried out by Taipale et al. (2011) confirmed the hypothesis that the autonomy positively influences work engagement. Task variety refers to the degree to which a job requires employees to perform a wide range of tasks on the job (Morgeson \& Humphrey, 2006). Thus, jobs, involving wider variety of tasks, are more interesting, provide higher satisfaction and result in work engagement. Thus, some studies performed by scholars disclosed positive relationship between task variety and work engagement (Zaniboni et al., 2014).

Finally, job feedback is related to the direct and clear information about the effectiveness of performed tasks (Morgeson \& Humphrey, 2006). Notably, the focus is on feedback directly from the job itself or knowledge of one's own work activities, as opposed to feedback from others. The opinion prevails that job feedback expands the knowledge about the work results (Morgeson \& Humphrey, 2006). Meanwhile, some scholars expanded the extant knowledge of job feedback by adding work environment, defined by good atmosphere and managers' support, resulting in work engagement of employees (Taipale et al., 2011).

\subsection{Employee related factors}

Another stream of investigations, focused on work engagement, distinguish employee related factors. For instance, some studies emphasize the significance of career-related pull factors and entrepreneurial orientation influencing participation of older employees in the labor market (Davis, 2003). Notably, the breaks of career influence early retirement or stimulate financial needs to continue work (Dixon, 2003). Meanwhile, Phillipson and Smith (2006) emphasized the importance of learning and development, impacting work engagement. Their study identified how employers could encourage employees to postpone the retirement. 
The suggestions include opportunities of life-long learning, supporting environment for women and opportunities of flexible employment (Phillipson \& Smith, 2006).

Commitment to work is seen as one of the most important aspects interrelated to work engagement. The researches disclosed that effectiveness and commitment of employees motivate them to remain with employer and consequently increase employees' work engagement (Adams \& Rau, 2004). Meanwhile, Mor-Barak (1995) has noticed that older employees tend to be engaged when they have the opportunity to share their knowledge with younger colleagues. This factor is relevant to the employees who are approaching the retirement age. The retirement is determined by various factors which are non-directly interrelated with experiences in job places. The investigations of human capital let the scholars distinguish some employee related factors (Prakapavičiūtė \& Korsakienè, 2016). For instance, appropriate skills, required for particular jobs, influence the employment opportunities of older employees (Flynn, 2010; Raišienè et al., 2015; Korsakienè et al., 2017). Thus, the desire to remain longer in the labor market positively correlates with the employers' desire to retain employees with necessary skills (Loretto \& White, 2006). In addition, social support provided for older employees encourage them coordinate work and other responsibilities more efficiently (Adams \& Rau, 2004).

The analysis of factors, related to the experiences in job places let us conclude that the positive experiences influence the postponement of the retirement. On the other hand, negative experiences after retirement such as, unemployment period or economic shocks encourage the desire of individuals to remain in their jobs longer (Flynn, 2010). Finally, human resource management policies, developed by organizations, influence the attitudes of older employees. Thus, the organizations with more favorable policies retain older employees and increase their work engagement.

\subsection{Age related factors and demographic characteristics}

The retirement age influences the decision of individuals to come back to the labor market and vice versa. On the other hand, the longer individual is retired, the lower are stimulus to be active (Adams \& Rau, 2004). Meanwhile, Davis (2003) asserts that if retired individuals become disappointed with their situation, the desire to come back to the labor market increases. Finally, the studies disclosed differences among ethnic groups with different work experiences and their significance in comparing employment patterns, social relations and discrimination experiences (Flynn, 2010).

Majority of investigations aimed to reveal push and pull factors, encouraging older individuals to select the retirement, in order to detect willingness to later return on full-time or part-time basis. Notably, health is widely investigated factor in scientific literature. Undoubtedly, older employees, who withdraw from labor market due to the health issues, are less willing to start working again (Flynn, 2010). The retired individuals who experience health issues are most likely to be economically disadvantaged. Meanwhile, individuals with the need to take care of family members are less likely come back to labor market (Evandrou \& Glaser, 2003).

The influence of gender triggered scientific discussions and a number of scientific studies. Some scholars assert that women are more disappointed about longer work period of their life (Adamas \& Rau, 2004). Gender has dual effect on economic activity. The investigations disclosed that career breaks hinder the possibilities to maintain jobs of women before and after retirement age (Dixon, 2003). The trends of labor market have stronger impact if gender and particular jobs are considered. For instance, a number of jobs were lost in manufacturing industries in 1980's and 1990's in the UK. Meanwhile, economic crisis in Japan put at the risk the lifelong employment pattern (Flynn, 2010). 
Marital status was investigated by various scholars but the impact was differently observed. The studies suggested that marital status may be especially beneficial for men, seeking to improve and strengthen social relations while searching for job places (Arber et al., 2003). Notably, the spouse's retirement is also an important contributor. For instance, the decision of wife to retire could provoke the similar behavior of the spouse. Meanwhile, the divorce and the aim to care about children influence the aspiration to remain in the labor market longer and even in the age of the retirement (Lewis \& Smithson, 2006).

\section{Methodological approach}

The above presented discussion has led to the investigations of factors, impacting work engagement of older employees. The studies focused on older employees adopted different approaches. Some studies defined older employees as individuals who are aged 45 and up (De Lange et al., 2010; Kraak et al., 2017). Meanwhile other studies distinguished older employees who are aged 40-75 (Kooij et al., 2008) or suggested the following cohorts: young, middle-aged, and old employees (James et al., 2011; Goštautaitè, 2014). Hence, following prevailing studies we are going to focus on individuals who are aged 40-75. Considering prevailing approaches, work engagement is defined as a positive, fulfilling, work-related state of mind that is characterized by vigor, dedication, and absorption (Van Wingerden et al., 2017). Notably, work-related state of mind is long-term and non-related to the objects, events, individuals and their behaviour. The scholars characterized vigor by high levels of energy and mental resilience while working, the willingness to invest effort in one's work, and persistence even in the face of difficulties (Schaufeli \& Bakker, 2010). Meanwhile, dedication is referred to being strongly involved in one's work and experiencing a sense of significance, enthusiasm, inspiration, pride, and challenge (Van Wingerden et al., 2017). Finally, absorption is characterized by being fully concentrated and happily engrossed in one's work, where time passes quickly (Schaufeli \& Bakker, 2010).

The research was carried out in Vilnius - capital of Lithuania. The decision was based on the fact that employment rate in Vilnius county was $74,7 \%$ and was highest in Lithuania (Statistics Lithuania, 2016). The respondents were selected considering the following criteria: individuals were aged 40-75 and were active in the labour market. The respondents from science, study institutions and public organisations were selected considering the fact that their contacts were publicly available. Convenience sample was used. The questionnaire was developed and sent to 600 respondents in the autumn of 2016. The return percentage of questionnaires was not very high and reached $18 \%$.

\subsection{Variables and measures}

The first group of questions comprised work engagement characteristics from Utrecht work engagement scale (Schaufeli et al., 2006). The responses to the questions were assessed by applying Likert scale from 0 (never) to 6 (always). The example question is "At work, I am bursting with energy". The measures of work engagement were summed and the IID variable was developed. Work related questions comprised second group of questions and were grounded on Work Design Questionnaire (Morgeson \& Humphrey, 2006). The respondents had to score the items on a five-point scale, ranging from (1) strongly disagree to (5) strongly agree. The example question is: "The job allows me to make my own decisions about how to schedule my work". Grounded on prevailing Work Design Questionnaire, the questions were included in the questionnaire and the following variables were formed: work scheduling autonomy (DPA), decision making autonomy (SP), task variety (UI), task significance (US) and feedback from job (GR). Relying on previous studies, the third group of 
questions included employee related factors. Thus, the questions related to the managerial orientation (Davis, 2003), carrier achievement (Desmette \& Gaillard, 2008) were included. In addition, some questions related to the learning and development and dedication to work were developed by the authors. The items were measured on a five-point Likert scale ranging from (1) totally disagree to (5) totally agree. The example question is "I tend to consult younger employees". Notably, the following variables were formed: managerial orientation (VO), carrier achievement (KS), desire for learning and development (TM), dedication to work (AD) and desire to transfer professional experience to others (PP).

Meanwhile, age related questions included: chronological age, job tenure and organisational tenure. Chronological age was assessed by asking respondents to indicate their age and job tenure in current organisation. Job tenure (ProfP) referred to the following years: <5; [6-10]; [11-15]; [16-20]; >21. Meanwhile, organisational tenure referred to the tenure in current organisation. Demographic questions included gender, marital status, education, current job position and monthly incomes. Gender (Gend) was coded as follows: (1) men and (2) women. Marital status (Fam) comprised the following: single, married, divorced, widow. The education level (Edu) included from (1) secondary education to (5) high university education. Current job position (JPos) included from (1) other to (4) top manager. Monthly incomes (Inco) included the following range: $<400 € ;[401-600 €] ;[801-1000 €] ;>1001 €$.

\subsection{Analytical approach}

Construct validity was tested by Bartlett's test of sphericity, Kaiser-Meyer-Olkin test, and communalities. Construct reliability was conducted by applying Cronbach's alpha coefficient. Aiming to test if selected work related and employee related characteristics positively influence work engagement of older employees, Spearman correlation coefficients were calculated. Later on, regression analysis was applied.

\section{Results}

The data was collected from 107 respondents. However, majority of questionnaires were filled by women $(66 \%)$. The mean age of respondents was 53,96 years ( $\mathrm{SD}=9,74)$. Majority of respondents were married $(70 \%)$ and obtained high university education $(92 \%)$. As it was initially expected, majority of respondents (74\%) had longer than 21-year job tenure. Half of all respondents occupied specialists' jobs. Considering monthly incomes, $40 \%$ of respondents indicated 801-1000€, 29\% - more than $1001 €, 25 \%-401-600 €$ and $7 \%-$ less than $400 €$.

Table 1 (in Appendix 1) presents descriptive statistics. Notably, weak positive correlation is observed between work related characteristics and work engagement. Thus, the correlation is ranging from $\mathrm{r}=0,235(\mathrm{p}<0,05)$ (between task variety and work engagement) to $\mathrm{r}=0,483$ ( $\mathrm{p}<0,001)$ (between job feedback and work engagement). In addition, weak positive correlation is observed between employee related characteristics and work engagement. Thus, the correlation is ranging from $\mathrm{r}=0,24, \mathrm{p}<0,05$ (between desire for learning and development and work engagement) to $\mathrm{r}=0,478, \mathrm{p}<0,001$ (between managerial orientation and work engagement). Notably, moderate correlation is observed between dedication to work and work engagement $(r=, 508, p<0,001)$.

Bartlett's test for sphericity was significant (Chi-square $=4259,041 ; d f=1485$; $p<0,000)$ and Kaiser-Meyer-Olkin (KMO) measure of sampling adequacy equal to 0,774. These observations let us conclude that the data are appropriate for explanatory factor analysis. 
The number of factors was determined based on theoretical considerations. Notably, eleven factors solution was indicated using Principal component factors extraction method whereby $73,625 \%$ of the variance could be explained. Communalities were used to assess the proportion of the variance in each item explained by the extracted factors. Notably, all communalities ranged from 0,6 to 0,9 .

The reliability test was conducted by applying Cronbach's alpha coefficient. The data revealed that all constructs are valid and can be applied in statistical analysis (Table 2).

Table 2. Reliability of the study variables

\begin{tabular}{lc}
\hline \multicolumn{1}{c}{ Construct } & Cronbach's $\alpha$ value \\
\hline Work engagement & 0,878 \\
\hline Work scheduling autonomy & 0,85 \\
\hline Decision making autonomy & 0,834 \\
\hline Task variety & 0,857 \\
\hline Task significance & 0,777 \\
\hline Feedback from job & 0,833 \\
\hline Managerial orientation & 0,897 \\
\hline Carrier achievement & 0,782 \\
\hline Desire for learning and development & 0,767 \\
\hline Dedication to work & 0,787 \\
\hline Desire to transfer professional experience to others & 0,762 \\
\hline
\end{tabular}

Source: authors' calculation.

The assumption was made that selected work related and employee related characteristics and work engagement of older employees were non-linear. The obtained results revealed that weak and positive relationship exist between work scheduling autonomy $(\mathrm{r}=0,394 ; \mathrm{p}=0,000)$, decision making autonomy $(=0,378 ; \mathrm{p}=0,000)$; task significance $(\mathrm{r}=0,368$; $\mathrm{p}=0,000)$, feedback from work $(\mathrm{r}=0,483 ; \mathrm{p}=0,000)$, managerial orientation $(\mathrm{r}=0,478$; $\mathrm{p}=0,000)$, carrier achievement $(\mathrm{r}=0,444 ; \mathrm{p}=0,000)$, dedication to work $(\mathrm{r}=0,508 ; \mathrm{p}=0,000)$ and work engagement of older employees. Meanwhile, task variety $(\mathrm{r}=0,235 ; \mathrm{p}=0,015)$, desire for learning and development $(\mathrm{r}=0,240 ; \mathrm{p}=0,013)$, desire to transfer professional experience to others $(\mathrm{r}=0,252 ; \mathrm{p}=0,009)$ were non-linear and non-significant.

The findings of regression analysis are provided in Table 3. Notably, significant models explaining more than $10 \%$ of data variance are analysed. The analysis revealed the relationship between work scheduling autonomy and work engagement. The model is as follows: y (work engagement) $=0,73 \mathrm{x}+2,1213(\beta=, 429, \mathrm{t}=4,860, \mathrm{p}<.001)$. Model explains $19 \%$ of data variations. Meanwhile, the regression model between decision making autonomy and work engagement is as follows: $y$ (work engagement) $=0,6899 x+2,6175(\beta=, 494$, $\mathrm{t}=5,816, \mathrm{p}<.001)$. Model explains $26 \%$ of data variance. The regression model between feedback from work and work engagement is as follows: $y$ (work engagement) $=0,4887 \mathrm{x}+$ $3,5273$ ( $\beta=, 448, t=5,134, p<.001)$. Model explains 15 of data variance. The regression model between managerial orientation and work engagement is as follows: $y$ (work engagement) = $0,6003 \mathrm{x}+3,0781 \quad(\beta=, 541, \mathrm{t}=6,585, \mathrm{p}<.001)$. Model explains 15 of data variance. The regression model between career achievement and work engagement is as follows: $\mathrm{y}$ (work engagement $)=0,5624 x+3,3027(\beta=, 440, t=5,023, p<.001)$. Model explains 16 of data variance. The regression model between dedication to work and work engagement is as follows: $y$ (work engagement) $=0,829 x+1,6448(\beta=, 572, t=7,141, p<.001)$. Model explains 21 of data variance. 
Table 3. Results of regression analysis

\begin{tabular}{lrrrrr}
\hline \multicolumn{1}{c}{ Predictors } & \multicolumn{2}{c}{$\begin{array}{l}\text { Unstandardized } \\
\text { Coefficients }\end{array}$} & $\begin{array}{c}\text { Standardized } \\
\text { Coefficients }\end{array}$ & t & Sig. \\
\hline & \multicolumn{1}{c}{$\mathrm{B}$} & $\begin{array}{c}\text { Std. } \\
\text { Error }\end{array}$ & Beta & & \\
\hline (Constant) & 2,478 &, 607 & & 4,083 &, 000 \\
\hline Work scheduling autonomy &, 651 &, 134 &, 429 & 4,860 &, 000 \\
\hline (Constant) & 2,952 &, 428 & & 6,891 &, 000 \\
\hline Decision making autonomy &, 607 &, 104 &, 494 & 5,816 &, 000 \\
\hline (Constant) & 3,620 &, 424 & & 8,544 &, 000 \\
\hline Feedback from work &, 519 &, 101 &, 448 & 5,134 &, 000 \\
\hline (Constant) & 2,962 &, 378 & & 7,835 &, 000 \\
\hline Managerial orientation &, 632 &, 096 &, 541 & 6,585 &, 000 \\
\hline (Constant) & 3,376 &, 411 & & 8,211 &, 000 \\
\hline Career achievement &, 562 &, 112 &, 440 & 5,023 &, 000 \\
\hline (Constant) & 1,114 &, 605 & & 1,842 &, 000 \\
\hline Dedication to work &, 946 &, 133 &, 572 & 7,141 &, 000 \\
\hline
\end{tabular}

Source: authors' calculation.

\section{Conclusion}

Scientific studies, focused on the issues of discrimination due to age and challenges faced by older employees in the work environment, have been expanding. The stereotypes related to lower productivity, inflexibility, lower interest towards organization and training of older employees, prevail in business society. Thus, the tendencies in some countries let us conclude that employers prefer younger than older employees. The changes of some negative attitudes towards older employees and prevailing stereotypes require considerable efforts. On the other hand, unfavorable demographic trends let us predict higher employment rate of older employees in the nearest future. Hence, the issues related to work engagement of older employees is seen as the priority of top managers and human resource management professionals.

Though scientific studies distinguish various factors, impacting work engagement of older employees, we set forth to focus on work related factors, employee related factors and age-related factors. The research carried out and data obtained let us confirm that work scheduling autonomy, decision making autonomy, managerial orientation, career achievement, dedication to work, feedback from work influence work engagement of older employees. These data correspond to other studies carried out by other scholars (Taipale et al., 2011; Zaniboni et al., 2014). Surprisingly, task variety, desire for learning and development, desire to transfer professional experience to others did not disclose the relationship with work engagement.

The study has several implications for managers. The shortage of qualified workers due to demographic tendencies and emigration from Lithuania require putting emphasis on older employees and to develop specific measures how to increase their work engagement. Thus, improvement of lifelong learning, flexible employment opportunities and development of appropriate career opportunities have to be considered as the priority of human resource professionals. For instance, the possibilities to make decisions and to perform a wide range of tasks are the appropriate ways leading to the increased engagement of employees. Constant feedback provided by the managers and positive atmosphere at work, respectful relationships with older employees despite their job position and subordination should be considered as 
well. The managers are suggested communicate and emphasize constantly the value created due to loyalty, knowledge and skills of older employees. In addition, all possible forms of discrimination due to age and consequently increasing conflicts between different generations in the work environment should be prevented. The attitude to the positive relationships between managers and subordinates could facilitate work engagement of older employees and their desire to remain active in the labor market.

The findings of presented study are limited in several ways. First, the research considered only some work, employee and age-related factors. Thus, future investigations have to include other factors and their impact on performance of older employees. Second, the study focused on individuals working in science, education and public organisations and thus, future investigations have to consider particular industries. Third, the study was conducted in the context of one country and future investigations might target other countries.

\section{References}

Adams, G. A., Rau, B. L. (2004). Job seeking among retirees seeking bridge employment. Personnel Psychology, 57(3), 719-744.

Arber, S., Davidson, S., Daly, T., Perren, K. (2003). Older Men: Their Social Worlds and Healthy Lifestyles. NIACE, Leicester, p. 53.

Armstrong-Stassen, A., Ursel, N. D. (2009). Perceived organizational support, career satisfaction, and the retention of older workers. Journal of occupational and organisational psychology, 82(1), 201-220.

Bejtkovský, J. (2016). The Employees of Baby Boomers Generation, Generation X, Generation Y and Generation Z in Selected Czech Corporations as Conceivers of Development and Competitiveness in their Corporation. Journal of Competitiveness, 8(4), 105-123. DOI: 10.7441/joc.2016.04.07

Davis, M. A. (2003). Factors related to bridge employment participation among private sector early retirees. Journal of Vocational Behavior, 63(1), 55-71.

De Lange, A. H., Taris, T. W., Jansen, P. G. W., Kompier, M. A. J., Houtman, I. L. D., Bongers, P. M. (2010). On the relationships among work characteristics and learningrelated behavior: Does age matter? Journal of Organizational Behavior, 31, 925-950.

Department of Economic and Social Affairs Population Division (2015). World population ageing 2015. Available on Internet:

<http://www.un.org/en/development/desa/population/publications/pdf/ageing/WPA2015_R eport.pdf $>$.

Desmette, D., Gaillard, M. (2008). When a "worker" becomes an "older worker. Career Development International, 13(2), 168-185.

Dixon, S. (2003). Implications of population ageing for the labour market. Labour Market Trends, 111(2), 67-76.

Eurostat (2016). Employment statistics. Available on Internet: <http://ec.europa.eu/eurostat/statistics-explained/index.php/Employment_statistics>.

Evandrou, M., Glaser, K. (2003). Combining work and family life: the pension penalty of caring. Ageing and Society, 23(5), 583-601.

Flynn, M. (2010). Who would delay retirement? Typologies of older workers. Personnel Review, 39(3), 308-324.

Goštautaite, B. (2014). Age, work engagement and individual work performance: the influence of work design. Doctoral Dissertation Vilnius, p. 204. ISBN 978-9955-792-46-8.

Goštautaite, B., Bučiūnienè, I. (2015). The role of work characteristics in enhancing older employees' performance: evidence from a post-Soviet country. The International Journal of Human Resource Management, 26(6), 757-782. 
Humphrey, S. E., Nahrgang, J. D., Morgeson, F. P. (2007). Integrating motivational, social, and contextual work design features: A meta-analytic summary and theoretical extension of the work design literature. Journal of Applied Psychology, 92(5), 1332-1356.

James, J. B., McKechnie, S., Swanberg, J. (2011). Predicting employee engagement in an age-diverse retail workforce. Journal of Organizational Behavior, 32(2), 173-196.

Kooij, D., de Lange, A. H., Jansen, P., Dikkers, J. (2008). Older workers' motivation to continue to work: five meanings of age. Journal of Managerial Psychology, 23(4), 364-394.

Korsakienė, R., Liučvaitienè, A., Bužavaitè, M., Šimelytè, A. (2017). Intellectual capital as a driving force of internationalization: a case of Lithuanian SMEs. Entrepreneurship and sustainability issues, 4(4), 502-515.

Kraak, J. M., Lunardo, R., Herrbach, O., Durrieu, F. (2017). Promises to employees' matter, self-identity too: Effects of psychological contract breach and older worker identity on violation and turnover intentions. Journal of Business Research, 70, 108-117.

Lewis, S., Smithson, J. (2006). Final Report on the Project "Gender, Parenthood and the Changing European Workplace: Young Adults Negotiating the Work-Family Boundary: Transitions", Research Institute for Health and Social Change, Manchester Metropolitan University, Manchester, p. 140.

Statistics Lithuania (2016). Available on internet: <https://osp.stat.gov.lt/>

Loretto, W., White, P. (2006). Work, more work, and retirement: older workers' perspective. Social Policy \& Society, 5(4), 479-483.

Mor-Barak, M. E. (1995). The meaning of work for older adults seeking employment: the generativity factor. International Journal of Aging and Human Development, 41(4), 325-344.

Morgeson, F. P., Humphrey, S. E. (2006). The Work Design Questionnaire (WDQ): Developing and validating a comprehensive measure for assessing job design and the nature of work. Journal of Applied Psychology, 91(6), 1321-1339.

Park, J., Gursoy, D. (2012). Generation effects on work engagement among U.S. hotel employees. International Journal of Hospitality Management, 31(4), 1195-1202.

Prakapavičiūtè, J., Korsakienè, R. (2016). The investigation of human capital and investments into human capital: Lithuania in the context of the EU. Entrepreneurship and sustainability issues, 3(4), 350-367.

Raišienè, A. G., Korsakienè, R., Lace, N. (2015). How do Inter-institutional Teams Succeed? A Case of National Project. Economics and Sociology, 8(1), 7-18.

Schaufeli, W. B., Bakker, A. B. (2010). The conceptualization and measurement of work engagement: A review. In A. B. Bakker \& M. P. Leiter (Eds.), Work engagement: A handbook of essential theory and research. New York, NY: Psychology Press.

Schaufeli, W. B., Bakker, A. B., Salanova, M. (2006). The measurement of work engagement with a short questionnaire: A cross-national study. Educational and Psychological Measurement, 66, 701-716.

Taipale, S., Selander, K., Anttila, T., Nätti, J. (2011). Work engagement in eight European countries: the role of job demands, autonomy, and social support. International Journal of Sociology and Social Policy, 31(7/8), 486-504.

Van Wingerden, J., Derks, D., Bakker, A. B. (2017). The Impact of Personal Resources and Job Crafting Interventions on Work Engagement and Performance. Human Resource Management, 56(1), 51-67.

Zaniboni, S., Truxillo, D. M., Fraccaroli, F., McCune, E. A., Bertolino, M. (2014). Who benefits from more tasks? Older versus younger workers. Journal of Managerial Psychology, 29(5), 508-523. 